\title{
Catalytic conversion of methyl chloride to lower olefins over modified H-ZSM-34
}

\author{
Ting Xu, Hang Song, Weiping Deng\#, Qinghong Zhang, Ye Wang* \\ State Key Laboratory of Physical Chemistry of Solid Surfaces, Collaborative Innovation Center of Chemistry for Energy Materials, National \\ Engineering Laboratory for Green Chemical Productions of Alcohols, Ethers and Esters, College of Chemistry and Chemical Engineering, \\ Xiamen University, Xiamen 361005, Fujian, China
}

\section{A R T I C L E I N F O}

Article history:

Received 4 July 2013

Accepted 16 August 2013

Published 20 November 2013

\section{Keywords:}

Methyl chloride

Lower olefins

H-ZSM-34

Ethylenediaminetetraacetate treatment Cerium modification

Acidity

\begin{abstract}
A B S T R A C T
Among several typical zeolites, H-ZSM-34 was found to be an efficient catalyst for the conversion of methyl chloride to lower olefins, i.e., ethylene, propylene, and butenes. Treatment of H-ZSM-34 with a $\mathrm{Na}_{2} \mathrm{H}_{2}$ EDTA (EDTA = ethylenediaminetetraacetate) aqueous solution followed by ion exchange and calcination enhanced the catalytic performance significantly. The selectivity to lower olefins increased significantly for certain $\mathrm{Na}_{2} \mathrm{H}_{2}$ EDTA aqueous solution concentrations; when the H-ZSM-34 catalyst was treated with a $0.1 \mathrm{~mol} / \mathrm{L} \mathrm{Na}_{2} \mathrm{H}_{2}$ EDTA solution, the selectivity and yield of $\mathrm{C}_{2}-\mathrm{C}_{4}$ olefins reached $82 \%$ and $61 \%$, respectively, at $673 \mathrm{~K}$ and a $\mathrm{CH}_{3} \mathrm{Cl}$ partial pressure of $9.2 \mathrm{kPa}$. The modification of H-ZSM-34 with Ce ions improved $\mathrm{C}_{2}-\mathrm{C}_{4}$ olefin selectivity and yield. Catalyst characterization suggests that treatment with $\mathrm{Na}_{2} \mathrm{H}_{2}$ EDTA or modification by Ce decreases the acidity of H-ZSM-34. The weakened acidity of the treated or modified H-ZSM-34 may suppress the hydrogen transfer reaction and prevent lower olefins from further transformation to paraffins.
\end{abstract}

(C) 2013, Dalian Institute of Chemical Physics, Chinese Academy of Sciences. Published by Elsevier B.V. All rights reserved.

\section{Introduction}

Lower olefins, in particular ethylene and propylene, are among the most important building-block chemicals. Ethylene and propylene are primarily produced from petroleum via steam cracking of naphtha. The demand for the lower olefins has grown rapidly in recent years. There is a strong incentive to develop non-petroleum routes for the production of lower olefins to reduce reliance on diminishing petroleum sources. The production of lower olefins via novel routes such as the dehydrogenation of lower paraffins [1] and the methanol-to-olefins (MTO) process $[2,3]$ has attracted much attention.

Methane is the main constituent of natural gas, coal-bed gas, shale gas, landfill gas, biogas, and methane hydrates. The transformation of abundant and affordable methane resources to key building-block chemicals such as lower olefins is one of the most important research goals in catalysis. Current technology for chemical use of methane involves high-temperature steam reforming to produce syngas and the subsequent conversion to methanol, followed by methanol transformation to chemicals (e.g., propylene and ethylene). However, steam reforming of methane is an energy- and cost-intensive process [4]. Many studies have been devoted to the direct transformation of methane to chemicals such as methanol, formaldehyde, and ethylene, but yields of desired products are low [4-9]. The development of novel catalytic routes for the trans-

\footnotetext{
*Corresponding author. Tel: +86-592-2186156; Fax: +86-592-2183047; E-mail: wangye@xmu.edu.cn \# Corresponding author. Tel: +86-592-2180480; Fax: +86-592-2183047; E-mail: dengwp@xmu.edu.cn This work was supported by the National Basic Research Program of China (2010CB732303), the National Natural Science Foundation of China (21173174, 20923004, 21033006, and 21161130522), and the Program for Changjiang Scholars and Innovative Research Team in University (IRT1036). 
formation of methane to building-block chemicals is of high significance from a practical and fundamental point of view.

Recently, we reported a two-step route for the conversion of methane to lower olefins, particularly $\mathrm{C}_{3} \mathrm{H}_{6}$, via $\mathrm{CH}_{3} \mathrm{Cl}$ or $\mathrm{CH}_{3} \mathrm{Br}$ [10].

Step 1: $\mathrm{CH}_{4}+\mathrm{HCl}(\mathrm{HBr})+1 / 2 \mathrm{O}_{2} \rightarrow \mathrm{CH}_{3} \mathrm{Cl}\left(\mathrm{CH}_{3} \mathrm{Br}\right)+\mathrm{H}_{2} \mathrm{O}$

Step 2: $\quad \mathrm{CH}_{3} \mathrm{Cl}\left(\mathrm{CH}_{3} \mathrm{Br}\right) \rightarrow 1 / n \mathrm{C}_{n} \mathrm{H}_{2 n}(n=2-4)+\mathrm{HCl}(\mathrm{HBr})$

Net: $\quad \mathrm{CH}_{4}+1 / 2 \mathrm{O}_{2} \rightarrow 1 / n \mathrm{C}_{n} \mathrm{H}_{2 n}(n=2-4)+\mathrm{H}_{2} \mathrm{O}$

The $\mathrm{HCl}$ or $\mathrm{HBr}$ generated in the second step can be used directly in the first step, and the net reaction is the oxidative dehydrogenation of methane to lower olefins, i.e., Eq. (3).

The key to realizing this novel two-step route is to develop efficient catalysts for both steps. Some catalysts such as $\mathrm{Ru} / \mathrm{SiO}_{2}$ [11], $\mathrm{Rh} / \mathrm{SiO}_{2}$ [12], $\mathrm{FePO}_{4} / \mathrm{SiO}_{2}$ [13], $\mathrm{LaOCl}$ [14-16], and $\mathrm{CeO}_{2}$ [10] have been studied for use in Step 1, i.e., the oxidative chlorination or bromination of methane to $\mathrm{CH}_{3} \mathrm{Cl}$ or $\mathrm{CH}_{3} \mathrm{Br}$ by $\mathrm{HCl}$ or $\mathrm{HBr}$ in the presence of $\mathrm{O}_{2}$. This work is devoted to studying catalysts for Step 2.

Some studies have investigated catalysts for the conversion of methyl halides to light olefins. H-SAPO-34 is an efficient catalyst for the MTO process [2,3,17-19]. Because of the chemical similarities between methyl halides and methanol, H-SAPO-34 has been employed mainly as a catalyst for the formation of light olefins in methyl halide conversion [20-25]. We have demonstrated that $\mathrm{H}-\mathrm{ZSM}-5$ is a highly efficient catalyst for the conversion of methyl halides $\left(\mathrm{CH}_{3} \mathrm{Cl}\right.$ and $\left.\mathrm{CH}_{3} \mathrm{Br}\right)$ to $\mathrm{C}_{2}-\mathrm{C}_{4}$ olefins, particularly $\mathrm{C}_{3} \mathrm{H}_{6}$, after modification such as by $\mathrm{NH}_{4} \mathrm{~F}$ treatment $[10,26]$.

In addition to SAPO-34 and H-ZSM-5, H-ZSM-34 is also a promising catalyst for the formation of lower olefins. ZSM-34 zeolite, which is an intergrowth of erionite and offretite, has an open micropore size of $\sim 0.50 \mathrm{~nm}[27,28]$. The pore size for ZSM-34 is between that for SAPO-34 $(0.38-0.42 \mathrm{~nm})$ and ZSM-5 (0.52-0.56 nm). Several research groups have reported that H-ZSM-34 exhibits unique product selectivities for the conversion of methanol to olefins [29-31]. In this paper, for the first time, we report on the catalytic behavior of H-ZSM-34 for the conversion of $\mathrm{CH}_{3} \mathrm{Cl}$ to lower olefins, which is key in the two-step production of lower olefins from methane [10]. The modification of H-ZSM-34 to enhance its catalytic performance and the key factors determining the catalytic behavior will also be discussed.

\section{Experimental}

\subsection{Catalyst preparation}

Zeolites including H-ZSM-5, SAPO-34, SAPO-11, H- $\beta$, H-MOR, and HY were purchased from Nankai University Catalyst Co. Na-ZSM-34 was synthesized using an organic template-free procedure reported by Xiao and co-workers [28]. In brief, $3.5 \mathrm{~g}$ $\mathrm{NaAlO}_{2}, 7 \mathrm{~g} \mathrm{NaOH}, 22 \mathrm{~g} \mathrm{KOH}$, and $67.5 \mathrm{~g}$ aqueous silica gel (40\%) were stirred and aged at room temperature for $72 \mathrm{~h}$ and produced a clear solution denoted as L seed. $\mathrm{NaOH}$ (5.54 g) and fumed silica (28.85 g) were added to $83 \mathrm{~mL}$ water and stirred for $5 \mathrm{~h} . \mathrm{Al}_{2}\left(\mathrm{SO}_{4}\right)_{3} \cdot 18 \mathrm{H}_{2} \mathrm{O}(2.71 \mathrm{~g})$ and the $\mathrm{L}$ seed $(13.5 \mathrm{~mL})$ were introduced into the mixture, followed by further stirring for 13 h. The mixture was transferred into an autoclave to crystallize at $393 \mathrm{~K}$ for $7 \mathrm{~d}$. The product was collected by filtration, washing, and drying followed by calcination at $823 \mathrm{~K}$ in air for $5 \mathrm{~h}$ to obtain Na-ZSM-34. H-form ZSM-34 zeolite was prepared by the ion exchange of Na-ZSM-34 using $\mathrm{NH}_{4} \mathrm{NO}_{3}$ aqueous solution. Typically, $1.0 \mathrm{~g}$ powdered Na-ZSM-34 was added to $50 \mathrm{~mL}$ $\mathrm{NH}_{4} \mathrm{NO}_{3}$ aqueous solution (1.0 mol/L) and the suspension was stirred at $353 \mathrm{~K}$ for $3 \mathrm{~h}$. After filtration and washing, the sample was dried at $373 \mathrm{~K}$. This ion-exchange procedure was repeated three times, and the product was calcined at $823 \mathrm{~K}$ in air for $6 \mathrm{~h}$ to obtain H-ZSM-34.

The procedure for treating $\mathrm{H}-\mathrm{ZSM}-5$ with $\mathrm{Na}_{2} \mathrm{H}_{2} \mathrm{EDTA}$ (EDTA = ethylenediaminetetraacetate) is as follows. Typically, powdered H-ZSM-34 (2.0 g) was immersed into an aqueous solution of $\mathrm{Na}_{2} \mathrm{H}_{2}$ EDTA ( $\left.100 \mathrm{~mL}, 0-0.3 \mathrm{~mol} / \mathrm{L}\right)$ and the suspension refluxed at $373 \mathrm{~K}$. The solid product was recovered by filtration, washing with deionized water, and drying at $373 \mathrm{~K}$. Ion exchange of the $\mathrm{Na}^{+}$in the treated zeolite with $\mathrm{NH}_{4}{ }^{+}$was performed by adding the treated zeolite into an aqueous $\mathrm{NH}_{4} \mathrm{NO}_{3}$ solution (50 mL, $\left.1.0 \mathrm{~mol} / \mathrm{L}\right)$, followed by washing and drying at $373 \mathrm{~K}$. The ion exchange was repeated three times. $\mathrm{Na}_{2} \mathrm{H}_{2}$ EDTA-treated H-ZSM-34 was obtained after calcination at $823 \mathrm{~K}$ in air for $6 \mathrm{~h}$, and the sample was denoted H-ZSM-34EDTA or H-ZSM-34-EDTA- $x$, where $x$ is the concentration of $\mathrm{Na}_{2} \mathrm{H}_{2}$ EDTA.

Rare earth metal ion-modified H-ZSM-34 samples were also synthesized using a procedure similar to that for the synthesis of parent $\mathrm{H}-\mathrm{ZSM}-34$, with the introduction of rare earth metal salts into the mixture of $\mathrm{NaOH}$, fumed silica, and $\mathrm{Al}_{2}\left(\mathrm{SO}_{4}\right)_{3}$. $18 \mathrm{H}_{2} \mathrm{O}$ before hydrothermal synthesis for Na-ZSM-34. The sample obtained was denoted RE-H-ZSM-34 (RE represents a rare earth metal). The molar ratio of $\mathrm{RE}$ to $\mathrm{Al}$ in this series of samples was controlled at 0.080 .

\subsection{Catalyst characterization}

Inductively coupled plasma mass spectrometry (ICP-MS) measurements were performed with an Agilent ICP-MS 4500 to measure catalyst composition. Powder X-ray diffraction (XRD) patterns were recorded on a Panalytical X'pert Pro diffractometer with $\mathrm{Cu} K_{\alpha}$ radiation $(40 \mathrm{kV}, 30 \mathrm{~mA})$. Ar physisorption was used to gain information about the pore structure of catalysts and was performed at $87 \mathrm{~K}$ on a Micromeritics ASAP-2010M instrument. The pore size distribution in the microporous region was evaluated by the Horváth-Kawazoe (HK) method.

$\mathrm{NH}_{3}$ temperature-programmed desorption ( $\mathrm{NH}_{3}$-TPD) was performed on a Micromeritics AutoChem 2920 II instrument to measure the acidity. Typically, the sample loaded in a quartz reactor was pretreated with high-purity He gas at $673 \mathrm{~K}$ for $1 \mathrm{~h}$. After cooling to $373 \mathrm{~K}, \mathrm{NH}_{3}$ adsorption was performed by switching the He flow to a $10 \% \mathrm{NH}_{3} / \mathrm{He}$ gas flow and maintained at $373 \mathrm{~K}$ for $1 \mathrm{~h}$. The gas phase or weakly adsorbed $\mathrm{NH}_{3}$ molecules were purged by high-purity He at the same temperature. $\mathrm{NH}_{3}$-TPD was performed in the He flow by raising the temperature to $1073 \mathrm{~K}$ at $10 \mathrm{~K} / \mathrm{min}$. The desorbed $\mathrm{NH}_{3}$ molecules were detected by a ThermoStar GSD 301 T2 mass spectrometer with signal of $m / e=16$. 
Pyridine-adsorbed Fourier transform infrared (FT-IR) measurements were performed with a Nicolet Avatar instrument equipped with an MCT detector with $4 \mathrm{~cm}^{-1}$ resolution. Typically, the sample (10 mg) was pressed into a self-supported wafer and placed in an in situ FT-IR cell. After pretreatment under vacuum at $673 \mathrm{~K}$ for $30 \mathrm{~min}$, the sample was cooled to $473 \mathrm{~K}$. Pyridine was adsorbed at $473 \mathrm{~K}$ onto the sample for a sufficient length of time. FT-IR spectra were recorded after gaseous or weakly adsorbed pyridine molecules were removed by evacuation at $473 \mathrm{~K}$.

${ }^{27} \mathrm{Al}$ magic-angle spinning nuclear magnetic resonance $\left({ }^{27} \mathrm{Al}\right.$ MAS NMR) was used to investigate the coordination environment of Al. Measurements were carried out on a Varian Infinity Plus AS400 spectrometer (Varian Inc.) operated at $104.26 \mathrm{MHz}$ frequency, $0.5 \mu$ s pulse width, $50 \mathrm{G}$ radiofrequency field strength, $0.5 \mathrm{~s}$ pulse delay, and $7 \mathrm{kHz}$ spinning rate and with 85 000 scans.

\subsection{Catalytic reaction}

The catalytic conversion of $\mathrm{CH}_{3} \mathrm{Cl}$ was carried out on a fixed-bed tubular quartz reactor operated at atmospheric pressure. The catalyst loaded in the reactor was pretreated in a $\mathrm{N}_{2}$ (purity > 99.999\%) gas flow at $673 \mathrm{~K}$ for $1 \mathrm{~h}$ before reaction. The reaction was started by introducing $\mathrm{CH}_{3} \mathrm{Cl}$ (purity > 99.99\%) diluted with $\mathrm{N}_{2}$. All products were analyzed using an on-line gas chromatograph equipped with TCD and FID detectors. An RT-PLOTQ column was used to separate the $\mathrm{CH}_{3} \mathrm{Cl}$ and carbon-containing products including $\mathrm{CH}_{4}, \mathrm{C}_{2}-\mathrm{C}_{4}$ paraffins $\left(\mathrm{C}_{2} \mathrm{H}_{6}, \mathrm{C}_{3} \mathrm{H}_{8}\right.$, and $\left.\mathrm{C}_{4} \mathrm{H}_{10}\right)$, and $\mathrm{C}_{2}-\mathrm{C}_{4}$ olefins $\left(\mathrm{C}_{2} \mathrm{H}_{4}, \mathrm{C}_{3} \mathrm{H}_{6}\right.$, and $\mathrm{C}_{4} \mathrm{H}_{8}$ ). A Porapak Q column was used to separate $\mathrm{N}_{2}$ and $\mathrm{CH}_{3} \mathrm{Cl}$. The amount of $\mathrm{CH}_{3} \mathrm{Cl}$ formed was calculated using $\mathrm{N}_{2}$ as an internal standard with a TCD detector. The amount of hydrocarbon product was quantified with an FID detector. The hydrocarbon product selectivity was calculated from the amount of hydrocarbon product (mol) divided by the total amount of the $\mathrm{CH}_{3} \mathrm{Cl}$ (mol) converted on a carbon basis. The $\mathrm{C}_{5+}$ hydrocarbons were typically condensed in an alkali cold-trap that was employed to capture $\mathrm{HCl}$, and thus were not detected by the RT-PLOTQ column. The selectivity to $\mathrm{C}_{5+}$ hydrocarbons was estimated by a normalization method, i.e., by subtraction of the selectivity to $\mathrm{C}_{1}-\mathrm{C}_{4}$ hydrocarbons from $100 \%$, and was typically less than $10 \%$ for the ZSM-34-based catalysts. In some cases, we removed the cold-trap and analyzed the $\mathrm{C}_{5+}$ hydrocarbons with the PLOTQ column and an FID detector. $\mathrm{C}_{5} \mathrm{H}_{10}, \mathrm{C}_{5} \mathrm{H}_{12}$, $\mathrm{C}_{6} \mathrm{H}_{12}, \mathrm{C}_{6} \mathrm{H}_{14}, \mathrm{C}_{7} \mathrm{H}_{14}, \mathrm{C}_{7} \mathrm{H}_{16}$, and benzene were identified as the main components of the $\mathrm{C}_{5+}$ hydrocarbons, and the total selectivity calculated from the amounts of these hydrocarbons (mol) was approximately 5\%-10\%. This also suggests that the normalization method is applicable to the calculation of selectivity to $\mathrm{C}_{5+}$ hydrocarbons. The carbon balance was calculated from the amount of product (mol) divided by the total amount of $\mathrm{CH}_{3} \mathrm{Cl}$ converted (mol). The carbon deposition was detected and became significant at long reaction times (for example, $\geq 3$ $\mathrm{h}$ for H-ZSM-34-based catalysts). The main components of the carbon deposited were various aromatics such as benzene, naphthalene, and their derivatives. Without considering carbon deposition, the carbon balance was typically better than $90 \%$ for all catalysts at a shorter reaction time (1 or $2 \mathrm{~h}$ ).

\section{Results and discussion}

\subsection{Catalytic performance of several typical zeolites}

Table 1 shows the catalytic performance of several typical $\mathrm{H}$-form zeolites for the conversion of $\mathrm{CH}_{3} \mathrm{Cl}$ at $673 \mathrm{~K}$. H-ZSM-5, $\mathrm{H}-\mathrm{ZSM}-34$, and $\mathrm{H}-\mathrm{SAPO}-34$ displayed the highest $\mathrm{CH}_{3} \mathrm{Cl}$ conversions. The yield of lower $\left(\mathrm{C}_{2}-\mathrm{C}_{4}\right)$ olefins was larger than $35 \%$ over these three zeolite catalysts. The conversion of $\mathrm{CH}_{3} \mathrm{Cl}$ was lower than $30 \%$, and the yield of lower olefins was lower than $20 \%$ over other zeolites, although some (H- $\beta$, H-MCM-22, and H-MOR) exhibited comparable or higher selectivities to lower olefins. Among the three active catalysts, i.e., H-ZSM-5, H-ZSM-34, and H-SAPO-34, H-SAPO-34 was the most selective for the formation of lower olefins, but its $\mathrm{CH}_{3} \mathrm{Cl}$ conversion was the lowest. Compared with H-ZSM-5, H-ZSM-34 provided a higher selectivity to $\mathrm{C}_{2}-\mathrm{C}_{4}$ olefins although its conversion was lower. A comparison of catalytic performance between H-ZSM-34 (5.0) and H-Y (4.8) with similar Si/Al ratio showed that H-ZSM-34 had a higher $\mathrm{CH}_{3} \mathrm{Cl}$ conversion and $\mathrm{C}_{2}-\mathrm{C}_{4}$ olefin selectivity, and its yield of $\mathrm{C}_{2}-\mathrm{C}_{4}$ olefins was the highest. To the best of our knowledge, to date there has been no report on the conversion of methyl halides to lower olefins using H-ZSM-34. Thus, we have focussed on H-ZSM-34 for the conversion of

Table 1

Catalytic performance of several typical zeolites for the conversion of $\mathrm{CH}_{3} \mathrm{Cl}$.

\begin{tabular}{|c|c|c|c|c|c|c|c|c|c|c|}
\hline \multirow{2}{*}{ Catalyst a } & \multirow{2}{*}{$\begin{array}{c}\text { Conversion } \\
(\%)\end{array}$} & \multicolumn{6}{|c|}{ Selectivity ${ }^{\mathrm{b}}(\%)$} & \multicolumn{3}{|c|}{ Yield (\%) } \\
\hline & & $\mathrm{CH}_{4}$ & $\mathrm{C}_{2} \mathrm{H}_{4}$ & $\mathrm{C}_{3} \mathrm{H}_{6}$ & $\mathrm{C}_{4} \mathrm{H}_{8}$ & $\mathrm{C}_{2-4^{0}}$ & $\mathrm{C}_{5+}$ & $\mathrm{C}_{2} \mathrm{H}_{4}$ & $\mathrm{C}_{3} \mathrm{H}_{6}$ & $\mathrm{C}_{4} \mathrm{H}_{8}$ \\
\hline H-ZSM-5 (100) & 89 & 1.4 & 18 & 16 & 5.6 & 37 & 22 & 16 & 15 & 5.2 \\
\hline H-ZSM-34 (3.3) & 72 & 3.5 & 29 & 21 & 7.7 & 31 & 7.8 & 21 & 15 & 5.6 \\
\hline H-ZSM-34 (5.0) & 67 & 4.3 & 31 & 23 & 10 & 26 & 5.1 & 21 & 16 & 6.9 \\
\hline H-SAPO-34 & 50 & 1.1 & 46 & 32 & 0.5 & 19 & 0.9 & 23 & 16 & 0.3 \\
\hline H-SAPO-11 & $<1$ & - & - & - & - & - & - & - & - & - \\
\hline$H-\beta(50)$ & 26 & 0.4 & 20 & 31 & 20 & 16 & 12 & 5.3 & 8.3 & 5.2 \\
\hline H-MCM-22 (30) & 16 & 1.5 & 10 & 37 & 28 & 12 & 12 & 1.6 & 5.7 & 4.3 \\
\hline H-MOR (12) & 8.7 & 1.9 & 23 & 26 & 25 & 7.8 & 16 & 2.0 & 2.3 & 2.2 \\
\hline H-Y (4.8) & 24 & 0.5 & 12 & 17 & 19 & 20 & 30 & 2.9 & 4.1 & 4.6 \\
\hline
\end{tabular}

Reaction condition: catalyst $0.30 \mathrm{~g}, p\left(\mathrm{CH}_{3} \mathrm{Cl}\right)=3.3 \mathrm{kPa}, p\left(\mathrm{~N}_{2}\right)=98.0 \mathrm{kPa}, F=15.5 \mathrm{~mL} / \mathrm{min}, 673 \mathrm{~K}, 2 \mathrm{~h}$.

a $\mathrm{Si} / \mathrm{Al}$ ratio in parentheses.

${ }^{b} \mathrm{C}_{2-4}{ }^{0}$ and $\mathrm{C}_{5+}$ denote $\mathrm{C}_{2}-\mathrm{C}_{4}$ paraffins and hydrocarbons with carbon numbers $\geq 5$, respectively. 
$\mathrm{CH}_{3} \mathrm{Cl}$.

\subsection{Effect of modification on catalytic behavior of H-ZSM-34}

Although H-ZSM-34 catalyzed the conversion of $\mathrm{CH}_{3} \mathrm{Cl}$ to lower olefins with relatively better yields than other typical zeolites, the selectivity to the undesirable $\mathrm{C}_{2}-\mathrm{C}_{4}$ paraffin products $\left(\mathrm{C}_{2-4^{0}}\right)$ was still relatively high. The conversion of $\mathrm{CH}_{3} \mathrm{Cl}$ over H-ZSM-34 was also lower than that over H-ZSM-5 (Table 1). The change in reaction conditions by increasing the amount of catalyst and the $\mathrm{CH}_{3} \mathrm{Cl}$ partial pressure increases $\mathrm{CH}_{3} \mathrm{Cl}$ conversion to $>90 \%$ at $673 \mathrm{~K}$ and a time on stream of $1 \mathrm{~h}$, but the selectivity to $\mathrm{C}_{2}-\mathrm{C}_{4}$ paraffins also increases (Table 2). Thus, modification of the H-ZSM-34 to decrease selectivity to $\mathrm{C}_{2}-\mathrm{C}_{4}$ paraffins and increase that to lower olefins is a key research target.

We found that the treatment of H-ZSM-34 in an aqueous solution of $\mathrm{Na}_{2} \mathrm{H}_{2}$ EDTA followed by ion exchange with $\mathrm{NH}_{4}{ }^{+}$and calcination was an effective means to improve the selectivity to lower olefins. $\mathrm{Na}_{2} \mathrm{H}_{2}$ EDTA concentration influences catalytic behavior (Table 2). Under both reaction conditions, increasing $\mathrm{Na}_{2} \mathrm{H}_{2}$ EDTA concentration decreased $\mathrm{CH}_{3} \mathrm{Cl}$ conversion but increased selectivity to lower olefins, particularly $\mathrm{C}_{3} \mathrm{H}_{6}$ and $\mathrm{C}_{4} \mathrm{H}_{8}$, significantly. The selectivity to $\mathrm{C}_{2}-\mathrm{C}_{4}$ paraffins decreased significantly. The selectivity to $\mathrm{C}_{5+}$ hydrocarbons also decreased slightly. When the $\mathrm{Na}_{2} \mathrm{H}_{2}$ EDTA concentration reached 0.1
mol/L, the selectivities to $\mathrm{C}_{3} \mathrm{H}_{6}$ and $\mathrm{C}_{4} \mathrm{H}_{8}$ at $673 \mathrm{~K}$ were approximately twice those over H-ZSM-34 without treatment. The selectivity and yield of $\mathrm{C}_{2}-\mathrm{C}_{4}$ olefins were $82 \%$ and $61 \%$, respectively, over the H-ZSM-34-EDTA-0.1M. A further increase in $\mathrm{Na}_{2} \mathrm{H}_{2}$ EDTA concentration from 0.1 to $0.3 \mathrm{~mol} / \mathrm{L}$ led to a slight increase in selectivity to $\mathrm{C}_{3} \mathrm{H}_{6}$ and $\mathrm{C}_{4} \mathrm{H}_{8}$, but $\mathrm{CH}_{3} \mathrm{Cl}$ conversion decreased, resulting in a lower yield of lower olefins. Thus, an appropriate concentration of $\mathrm{Na}_{2} \mathrm{H}_{2}$ EDTA is required for the treatment of H-ZSM-34 to obtain the highest yield of lower olefins.

Modification of H-ZSM-34 with rare earth metal ions also improved the catalytic performance of H-ZSM-34. The introduction of rare earth metal ions into H-ZSM-34 can increase the selectivity to lower olefins (see Table 3), particularly of $\mathrm{C}_{3} \mathrm{H}_{6}$, and decrease that to $\mathrm{C}_{2}-\mathrm{C}_{4}$ paraffins under both reaction conditions. For instance, the presence of $\mathrm{La}, \mathrm{Ce}, \mathrm{Eu}$, and $\mathrm{Y}$ in H-ZSM-34 increased the selectivity for $\mathrm{C}_{3} \mathrm{H}_{6}$ to $>40 \%$, which was twice that over H-ZSM-34 without modification. However, significant decreases in $\mathrm{CH}_{3} \mathrm{Cl}$ conversion were observed over catalysts modified by $\mathrm{La}, \mathrm{Eu}$, and Y. Among the RE-H-ZSM-34 catalysts, Ce-H-ZSM-34 provided the best yield of lower olefins at $673 \mathrm{~K}$ (Table 3).

To gain insight into the effect of $\mathrm{Na}_{2} \mathrm{H}_{2}$ EDTA treatment and Ce modification on reaction pathways, we compared the catalytic behaviour of H-ZSM-34, H-ZSM-34-EDTA-0.1, and Ce-H-ZSM-34 for $\mathrm{CH}_{3} \mathrm{Cl}$ conversion with different contact times.

Table 2

Catalytic behavior of H-ZSM-34 samples treated with different concentrations of $\mathrm{Na}_{2} \mathrm{H}_{2} \mathrm{EDTA}$ aqueous solutions for conversion of CH $\mathrm{H}_{3} \mathrm{Cl}$.

\begin{tabular}{|c|c|c|c|c|c|c|c|c|c|c|}
\hline \multirow{2}{*}{$\begin{array}{l}\mathrm{Na}_{2} \mathrm{H}_{2} \text { EDTA concentration } \\
(\mathrm{mol} / \mathrm{L})\end{array}$} & \multirow{2}{*}{$\begin{array}{l}\text { Conversion } \\
(\%)\end{array}$} & \multicolumn{6}{|c|}{ Selectivity (\%) } & \multicolumn{3}{|c|}{ Yield (\%) } \\
\hline & & $\mathrm{CH}_{4}$ & $\mathrm{C}_{2} \mathrm{H}_{4}$ & $\mathrm{C}_{3} \mathrm{H}_{6}$ & $\mathrm{C}_{4} \mathrm{H}_{8}$ & $\mathrm{C}_{2-4^{0}}$ & $\mathrm{C}_{5+}$ & $\mathrm{C}_{2} \mathrm{H}_{4}$ & $\mathrm{C}_{3} \mathrm{H}_{6}$ & $\mathrm{C}_{4} \mathrm{H}_{8}$ \\
\hline $0^{\mathrm{a}}$ & 72 & 3.5 & 29 & 21 & 7.7 & 31 & 7.8 & 21 & 15 & 5.6 \\
\hline $0.1^{\text {a }}$ & 58 & 4.5 & 27 & 42 & 13 & 6.8 & 6.7 & 16 & 24 & 7.5 \\
\hline $0.2^{\mathrm{a}}$ & 52 & 5.1 & 28 & 41 & 14 & 5.3 & 6.4 & 15 & 21 & 7.3 \\
\hline $0.3^{\mathrm{a}}$ & 41 & 5.3 & 29 & 43 & 14 & 2.0 & 6.4 & 12 & 18 & 5.7 \\
\hline $0^{\mathrm{b}}$ & 92 & 1.8 & 26 & 20 & 5.2 & 40 & 7.0 & 24 & 18 & 4.8 \\
\hline $0.05^{b}$ & 88 & 2.0 & 28 & 24 & 7.0 & 32 & 7.0 & 24 & 21 & 6.1 \\
\hline $0.1^{\mathrm{b}}$ & 74 & 2.3 & 27 & 43 & 12 & 8.8 & 6.9 & 20 & 32 & 9.1 \\
\hline $0.2^{b}$ & 66 & 2.6 & 28 & 44 & 12 & 6.8 & 6.6 & 19 & 29 & 8.1 \\
\hline $0.3^{b}$ & 52 & 2.7 & 27 & 48 & 13 & 2.6 & 6.6 & 14 & 25 & 6.9 \\
\hline
\end{tabular}

a Reaction conditions: catalyst $0.30 \mathrm{~g}, p\left(\mathrm{CH}_{3} \mathrm{Cl}\right)=3.3 \mathrm{kPa}, p\left(\mathrm{~N}_{2}\right)=98.0 \mathrm{kPa}, F=15.5 \mathrm{~mL} / \mathrm{min}, 673 \mathrm{~K}, 2 \mathrm{~h}$.

b Reaction conditions: catalyst $0.70 \mathrm{~g} ; p\left(\mathrm{CH}_{3} \mathrm{Cl}\right)=9.2 \mathrm{kPa}, p\left(\mathrm{~N}_{2}\right)=92.1 \mathrm{kPa}, F=11 \mathrm{~mL} / \mathrm{min}, 673 \mathrm{~K}, 1 \mathrm{~h}$.

Table 3

Catalytic behavior of H-ZSM-34 samples modified with different rare earth metal ions for conversion of $\mathrm{CH}_{3} \mathrm{Cl}$.

\begin{tabular}{|c|c|c|c|c|c|c|c|c|c|c|}
\hline \multirow{2}{*}{ Modifier $^{a}$} & \multirow{2}{*}{$\begin{array}{c}\text { Conversion } \\
(\%)\end{array}$} & \multicolumn{6}{|c|}{ Selectivity (\%) } & \multicolumn{3}{|c|}{ Yield (\%) } \\
\hline & & $\mathrm{CH}_{4}$ & $\mathrm{C}_{2} \mathrm{H}_{4}$ & $\mathrm{C}_{3} \mathrm{H}_{6}$ & $\mathrm{C}_{4} \mathrm{H}_{8}$ & $\mathrm{C}_{2-4}{ }^{0}$ & $\mathrm{C}_{5+}$ & $\mathrm{C}_{2} \mathrm{H}_{4}$ & $\mathrm{C}_{3} \mathrm{H}_{6}$ & $\mathrm{C}_{4} \mathrm{H}_{8}$ \\
\hline None ${ }^{b}$ & 72 & 3.5 & 29 & 21 & 7.7 & 31 & 7.8 & 21 & 15 & 5.6 \\
\hline $\mathrm{La}^{\mathrm{b}}$ & 26 & 4.1 & 24 & 58 & 8.5 & 3.6 & 2.6 & 6.0 & 15 & 2.2 \\
\hline $\mathrm{Ce}^{\mathrm{b}}$ & 62 & 5.4 & 31 & 43 & 7.3 & 9.1 & 3.8 & 19 & 27 & 4.5 \\
\hline $\mathrm{Nd}^{\mathrm{b}}$ & 72 & 7.6 & 32 & 24 & 8.4 & 21 & 6.0 & 23 & 17 & 6.0 \\
\hline $\mathrm{Sm}^{\mathrm{b}}$ & 63 & 5.8 & 28 & 37 & 11 & 14 & 4.7 & 18 & 23 & 6.8 \\
\hline None $^{\mathrm{c}}$ & 92 & 1.8 & 26 & 20 & 5.2 & 40 & 7.0 & 24 & 18 & 4.8 \\
\hline $\mathrm{La}^{\mathrm{c}}$ & 33 & 2.1 & 21 & 55 & 15 & 4.6 & 2.3 & 7.1 & 18 & 5.1 \\
\hline $\mathrm{Ce}^{\mathrm{c}}$ & 79 & 2.8 & 29 & 41 & 6.3 & 13 & 7.9 & 23 & 32 & 5.0 \\
\hline $\mathrm{Nd}^{\mathrm{c}}$ & 91 & 3.9 & 29 & 25 & 5.7 & 31 & 5.4 & 17 & 22 & 5.1 \\
\hline $\mathrm{Sm}^{\mathrm{c}}$ & 80 & 3.0 & 25 & 35 & 8.0 & 18 & 11 & 20 & 28 & 6.6 \\
\hline $\mathrm{Eu}^{\mathrm{c}}$ & 40 & 3.5 & 28 & 45 & 14 & 7.2 & 2.3 & 11 & 18 & 5.4 \\
\hline $\mathrm{Y}^{\mathrm{c}}$ & 49 & 3.2 & 31 & 44 & 11 & 8.1 & 2.7 & 15 & 22 & 5.4 \\
\hline
\end{tabular}

a Molar ratio of rare earth metal to Al was controlled at 0.08 .

${ }^{\mathrm{b}}$ Reaction conditions: catalyst $0.30 \mathrm{~g}, p\left(\mathrm{CH}_{3} \mathrm{Cl}\right)=3.3 \mathrm{kPa}, p\left(\mathrm{~N}_{2}\right)=98.0 \mathrm{kPa}, F=15.5 \mathrm{~mL} / \mathrm{min}, 673 \mathrm{~K}, 2 \mathrm{~h}$.

c Reaction conditions: catalyst $0.70 \mathrm{~g}, p\left(\mathrm{CH}_{3} \mathrm{Cl}\right)=9.2 \mathrm{kPa}, p\left(\mathrm{~N}_{2}\right)=92.1 \mathrm{kPa}, F=11 \mathrm{~mL} / \mathrm{min}, 673 \mathrm{~K}, 1 \mathrm{~h}$. 

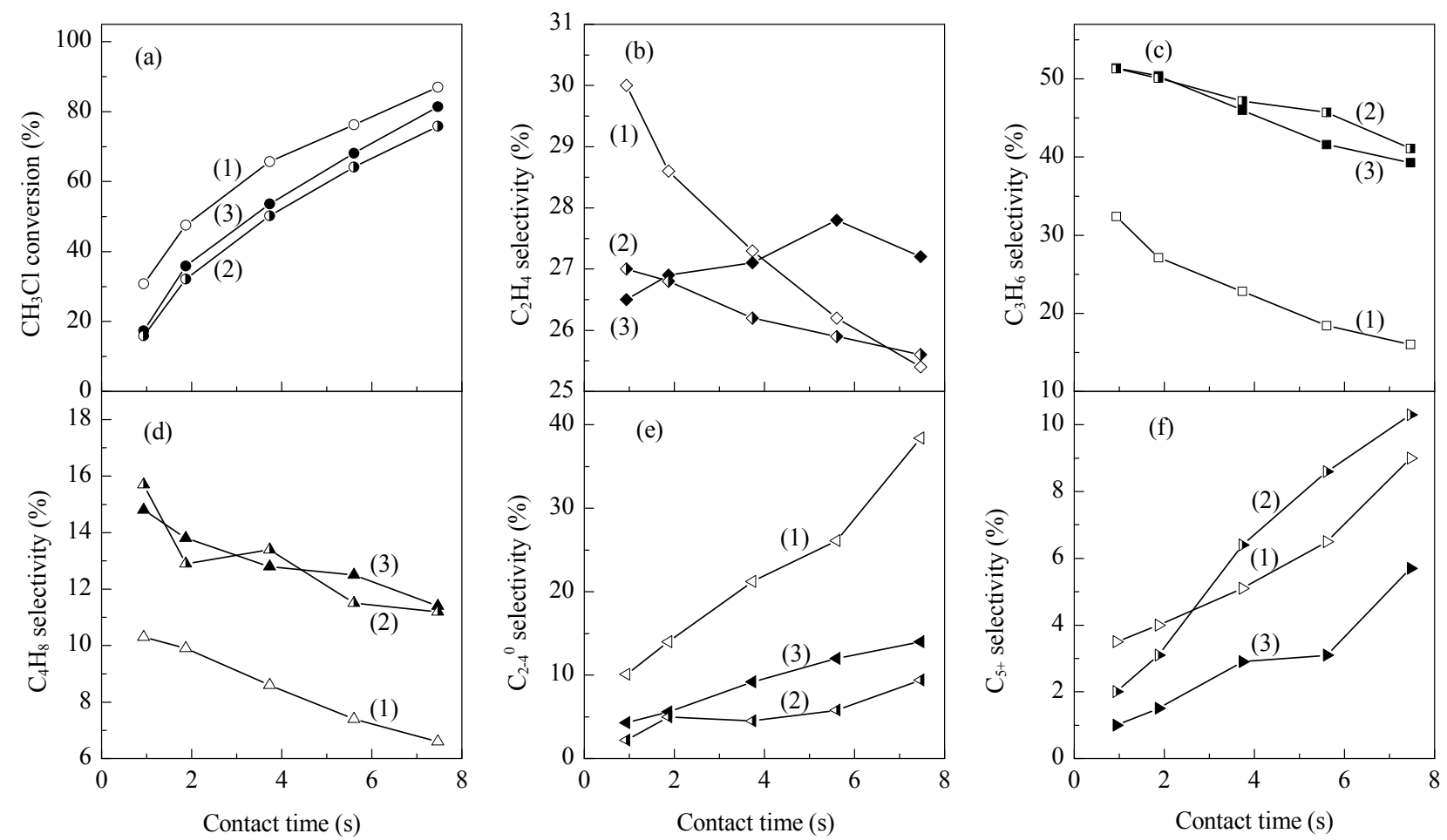

Fig. 1. Effect of contact time on catalytic behavior of H-ZSM-34 (1), H-ZSM-34-EDTA-0.1 (2), and Ce-H-ZSM-34 (3) for $\mathrm{CH}_{3} \mathrm{Cl}$ conversion. (a) $\mathrm{CH}_{3} \mathrm{Cl}$ conversion; (b) $\mathrm{C}_{2} \mathrm{H}_{4}$ selectivity; (c) $\mathrm{C}_{3} \mathrm{H}_{6}$ selectivity; (d) $\mathrm{C}_{4} \mathrm{H}_{8}$ selectivity; (e) $\mathrm{C}_{2}-\mathrm{C}_{4}$ paraffin selectivity; (f) $\mathrm{C}_{5+}$ hydrocarbon selectivity. Reaction conditions: $p\left(\mathrm{CH}_{3} \mathrm{Cl}\right)=9.2 \mathrm{kPa}, p\left(\mathrm{~N}_{2}\right)=92.1 \mathrm{kPa}, F=11 \mathrm{~mL} / \mathrm{min}, 673 \mathrm{~K}$.

As shown in Fig. 1(a), the conversion of $\mathrm{CH}_{3} \mathrm{Cl}$ increased almost linearly with contact time in the initial stage (shorter contact times) over the three catalysts. The H-ZSM-34-EDTA-0.1 and Ce-H-ZSM-34 catalysts showed slightly lower $\mathrm{CH}_{3} \mathrm{Cl}$ conversions than H-ZSM-34 for the same contact time. For H-ZSM-34, with shorter contact times (i.e., initial reaction stage), lower olefins, i.e., $\mathrm{C}_{2} \mathrm{H}_{4}, \mathrm{C}_{3} \mathrm{H}_{6}$, and $\mathrm{C}_{4} \mathrm{H}_{8}$, were formed as main products (Fig. 1(b-d)). An increase in contact time decreased the selectivity to lower olefins and increased that to $\mathrm{C}_{2}-\mathrm{C}_{4}$ paraffins (Fig. 1(e)) and $\mathrm{C}_{5+}$ hydrocarbons (Fig. 1(f)). These results suggest that, over H-ZSM-34, the lower olefins are the primary products, while the $\mathrm{C}_{2}-\mathrm{C}_{4}$ paraffins and $\mathrm{C}_{5+}$ hydrocarbons are secondary products formed from the lower olefins probably via hydrogen transfer and/or aromatization reactions. For the H-ZSM-34-EDTA-0.1 and Ce-H-ZSM-34 catalysts, the selectivity to lower olefins, particularly $\mathrm{C}_{3} \mathrm{H}_{6}$, also decreased with increasing contact time, but this decrease was lower than that for H-ZSM-34 without treatment or modification (Fig. 1(c)). The increase in selectivity to $\mathrm{C}_{2}-\mathrm{C}_{4}$ paraffins with contact time became less significant after $\mathrm{Na}_{2} \mathrm{H}_{2}$ EDTA treatment or Ce modification (Fig. 1(e)). These observations suggest that $\mathrm{Na}_{2} \mathrm{H}_{2}$ EDTA treatment and Ce modification of H-ZSM-34 suppress the hydrogen transfer reaction significantly.

Rapid catalyst deactivation was observed during the conversion of methyl halides over zeolite catalysts because of coke deposition [10,20-26]. We also investigated the stability of the H-ZSM-34, H-ZSM-34-EDTA-0.1, and Ce-H-ZSM-34 catalysts during $\mathrm{CH}_{3} \mathrm{Cl}$ conversion at $673 \mathrm{~K}$. Although $\mathrm{H}-\mathrm{ZSM}-34$ without modification showed a relatively higher $\mathrm{CH}_{3} \mathrm{Cl}$ conversion at a time on stream of $1 \mathrm{~h}$, rapid deactivation was observed (Fig. 2(a)). After $4 \mathrm{~h}, \mathrm{CH}_{3} \mathrm{Cl}$ conversion and lower olefin yield decreased significantly from $92 \%$ to $17 \%$ and from $47 \%$ to $13 \%$, respectively. $\mathrm{Na}_{2} \mathrm{H}_{2}$ EDTA treatment and Ce modification could improve catalyst stability. Figure 2(b) and (c) show that the decrease in $\mathrm{CH}_{3} \mathrm{Cl}$ conversion and the lower olefin yield become less rapid after $\mathrm{Na}_{2} \mathrm{H}_{2}$ EDTA treatment or Ce modification; the lower olefin yields of $49 \%$ and $47 \%$ could still be sustained after 4 h over the H-ZSM-34-EDTA-0.1 and Ce-H-ZSM-34 catalysts, respectively.

\subsection{Characterization of modified H-ZSM-34 catalysts}

Figure 3 shows the XRD patterns of the H-ZSM-34 catalysts treated with $\mathrm{Na}_{2} \mathrm{H}_{2}$ EDTA and modified with Ce ions. Diffraction peaks at $2 \theta=7.8^{\circ}, 11.9^{\circ}, 13.5^{\circ}, 20.6^{\circ}, 23.8^{\circ}, 25.0^{\circ}, 27.1^{\circ}, 28.5^{\circ}$, $31.4^{\circ}, 33.6^{\circ}$, and $36.3^{\circ}$, which could be ascribed to crystalline ZSM-34 [28,31], were observed for the $\mathrm{Na}_{2} \mathrm{H}_{2}$ EDTA-treated H-ZSM-34. However, the intensity of the diffraction peaks attributed to H-ZSM-34 became weaker at the higher concentration of $\mathrm{Na}_{2} \mathrm{H}_{2}$ EDTA used for H-ZSM-34 treatment. This suggests that the crystalline structure of H-ZSM-34 can be sustained after $\mathrm{Na}_{2} \mathrm{H}_{2}$ EDTA treatment, but the crystallinity decreases when a higher concentration of $\mathrm{Na}_{2} \mathrm{H}_{2}$ EDTA is used. For the Ce-modified H-ZSM-34, the main diffraction peaks attributed to the crystalline H-ZSM-34 were observed, but these peak intensities were lower than those for the parent H-ZSM-34. This suggests that the introduction of Ce species during the hydrothermal stage affects zeolite crystallinity. No diffraction peaks 


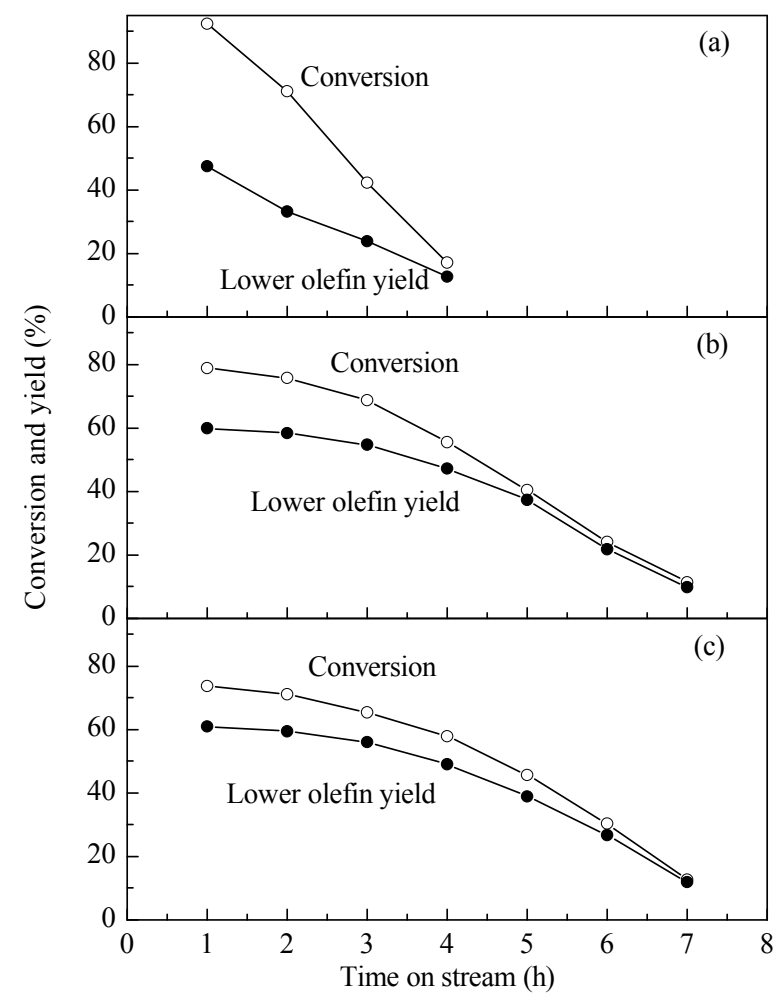

Fig. 2. Changes in catalytic performance with time on stream for $\mathrm{CH}_{3} \mathrm{Cl}$ conversion over H-ZSM-34 (a), H-ZSM-34-EDTA-0.1 (b), and Ce-H-ZSM-34 (c). Reaction conditions: catalyst $0.70 \mathrm{~g}, p\left(\mathrm{CH}_{3} \mathrm{Cl}\right)=9.2$ $\mathrm{kPa}, p\left(\mathrm{~N}_{2}\right)=92.1 \mathrm{kPa}, F=11 \mathrm{~mL} / \mathrm{min}, 673 \mathrm{~K}$.

assignable to Ce species could be detected, indicating that the Ce species might be well dispersed in the catalyst.

We measured the $\mathrm{Al}$ and Si contents in the H-ZSM-34 catalysts with $\mathrm{Na}_{2} \mathrm{H}_{2}$ EDTA treatment and $\mathrm{Ce}$ modification. As shown in Table 4, the Si/Al molar ratio for H-ZSM-34 was 3.3. The Si/Al ratio increased in the H-ZSM-34-EDTA. When the $\mathrm{Na}_{2} \mathrm{H}_{2}$ EDTA concentration for H-ZSM-34 treatment was increased from 0 to 0.1 and $0.3 \mathrm{~mol} / \mathrm{L}$, the $\mathrm{Si} / \mathrm{Al}$ ratio increased from 3.3 to 4.8 and 5.9. The decrease in $\mathrm{Al}$ content after $\mathrm{Na}_{2} \mathrm{H}_{2}$ EDTA treatment suggests the dealumination of H-ZSM-34 zeolite. The Ce-modified H-ZSM-34 (Ce-H-ZSM-34) catalyst

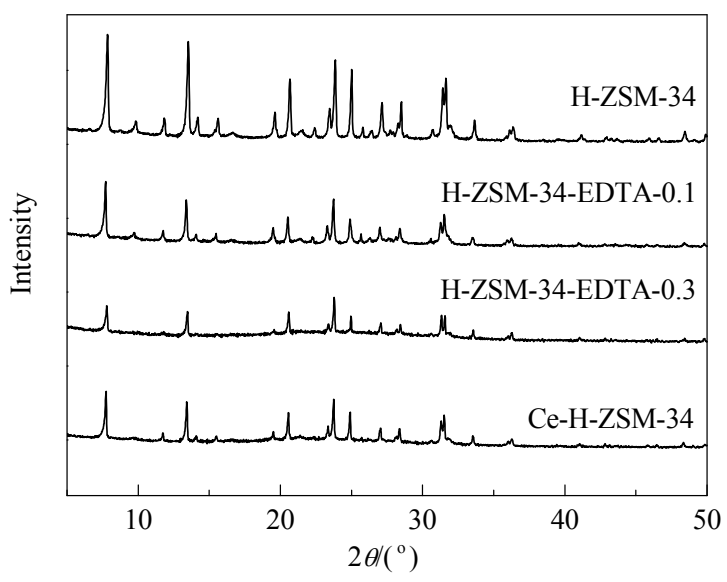

Fig. 3. XRD patterns for $\mathrm{H}-\mathrm{ZSM}-34$ samples treated with $\mathrm{Na}_{2} \mathrm{H}_{2}$ EDTA and modified with cerium together with parent H-ZSM-34.

Table 4

Composition of H-ZSM-34 catalysts treated with $\mathrm{Na}_{2} \mathrm{H}_{2}$ EDTA and modified with Ce.

\begin{tabular}{lccccc}
\hline \multirow{2}{*}{ Catalyst } & \multicolumn{3}{c}{ Composition ${ }^{\mathrm{a}}(\mathrm{wt} \%)$} & \multirow{2}{\mathrm{Si}/\mathrm{Al}}{} & $\begin{array}{c}\mathrm{Ce} / \mathrm{Al} \\
\text { molar ratio }\end{array}$ \\
\cline { 2 - 5 } & $\mathrm{Al}$ & $\mathrm{Si}$ & $\mathrm{Ce}$ & molar ratio \\
\hline H-ZSM-34 & 9.9 & 31 & - & 3.3 & - \\
H-ZSM-34-EDTA-0.1 & 7.4 & 34 & - & 4.8 & - \\
H-ZSM-34-EDTA-0.3 & 6.3 & 37 & - & 5.9 & - \\
Ce-H-ZSM-34 & 8.7 & 38 & 3.1 & 3.7 & 0.068 \\
\hline
\end{tabular}

a Measured by ICP.

possesses a slightly higher $\mathrm{Si} / \mathrm{Al}$ ratio (3.8) than the H-ZSM-34 without modification. Meanwhile, the $\mathrm{Ce} / \mathrm{Al}$ ratio was 0.068 for the Ce-H-ZSM-34 catalyst and the value was close to 0.08 , which was used in the synthesis gel, suggesting that Ce modification did not change the $\mathrm{Al}$ content in H-ZSM-34 significantly and most of the Ce ions could be incorporated into the catalyst.

Figure 4 shows the Ar adsorption-desorption isotherms and corresponding pore diameter distributions for our catalysts. All samples exhibit type-I isotherms, which are typical for microporous zeolites. Pore diameter distributions derived from the isotherms by the HK method show that our H-ZSM-34 without any treatment or modification possesses micropores $\sim 0.5 \mathrm{~nm}$ in size, which are typical for H-ZSM-34. After
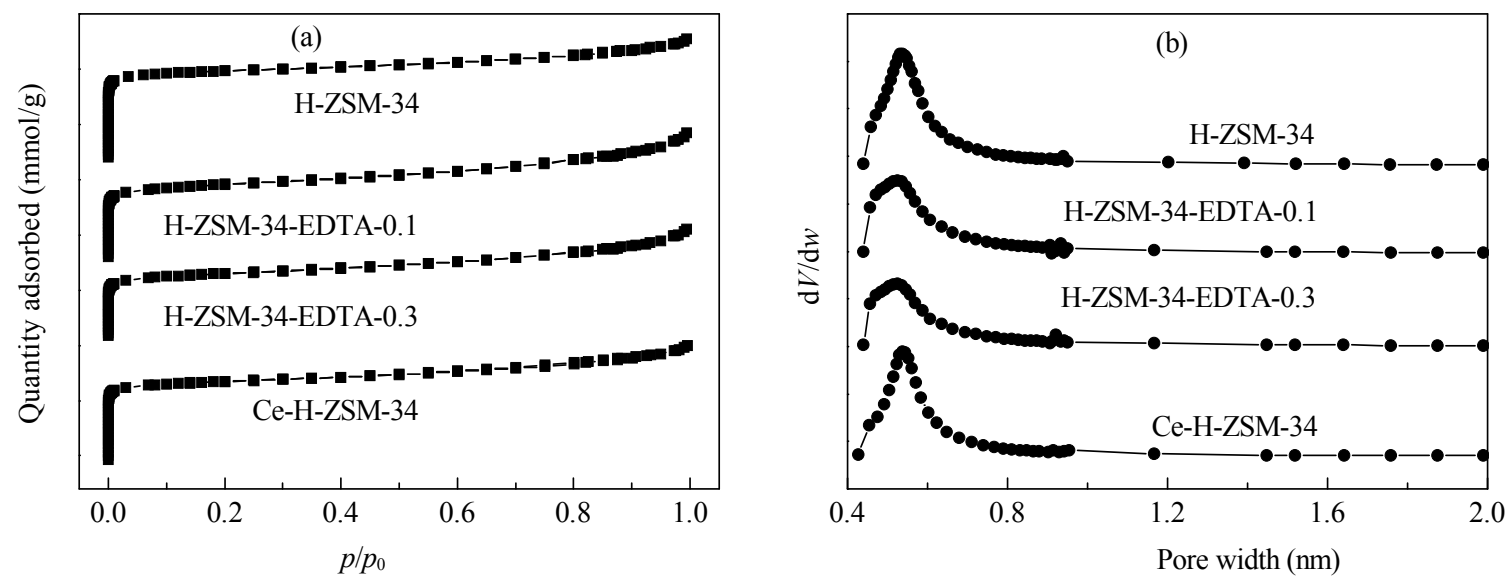

Fig. 4. Ar adsorption-desorption isotherms (a) and pore diameter distribution (b) of H-ZSM-34 samples derived from Ar physisorption isotherms by the HK method. 


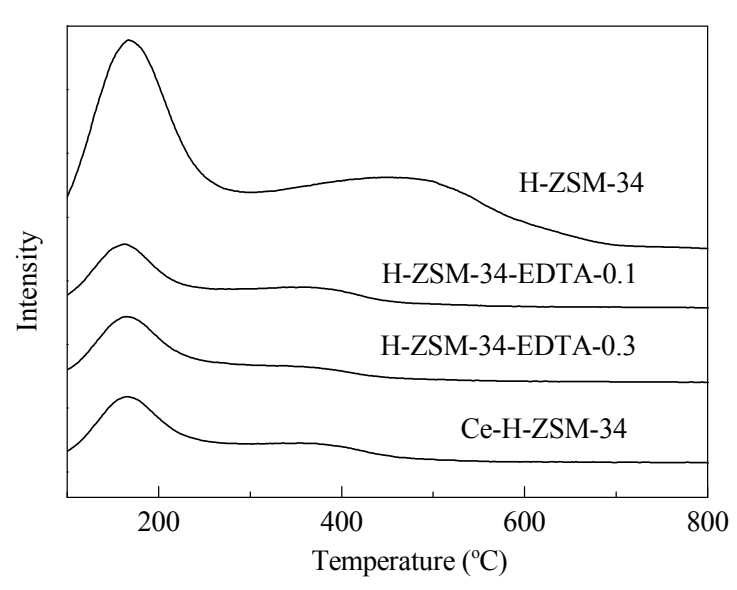

Fig. 5. $\mathrm{NH}_{3}$-TPD profiles for H-ZSM-34 samples treated with $\mathrm{Na}_{2} \mathrm{H}_{2}$ EDTA and modified with Ce together with parent H-ZSM-34.

$\mathrm{Na}_{2} \mathrm{H}_{2}$ EDTA treatment, pore diameter distributions become slightly broadened. This may result from dealumination from the H-ZSM-34 framework. For the Ce-modified sample (Ce-HZSM-34), the pore distribution was similar to that for H-ZSM-34. Thus, the pore structure for the Ce-HZSM-34 resembles that for HZSM-34.

Figure 5 shows the $\mathrm{NH}_{3}$-TPD profiles for $\mathrm{H}-\mathrm{ZSM}-34$, H-ZSM-34-EDTA, and Ce-H-ZSM-34. Two distinct $\mathrm{NH}_{3}$ desorption peaks at $\sim 473$ and $\sim 723 \mathrm{~K}$ were observed over H-ZSM-34, which could be attributed to the $\mathrm{NH}_{3}$ molecules adsorbed on weak and strong acid sites, respectively. After treatment with $\mathrm{Na}_{2} \mathrm{H}_{2}$ EDTA, the $\mathrm{NH}_{3}$ desorption peak intensity, particularly the higher-temperature peak, decreased significantly. The position of the higher-temperature peak shifted to lower temperatures. Thus, $\mathrm{Na}_{2} \mathrm{H}_{2}$ EDTA treatment decreased both the strength and density of the H-ZSM-34 acid sites. Based on this information and the ICP results (Table 4), we propose that dealumination by $\mathrm{Na}_{2} \mathrm{H}_{2}$ EDTA treatment causes the decrease in H-ZSM-34 acidity. Similarly, the strength and density of H-ZSM-34 acid sites also decreased because of Ce modification (Fig. 5). Since the $\mathrm{Si} / \mathrm{Al}$ ratio in the $\mathrm{Ce}-\mathrm{H}-\mathrm{ZSM}-34$ is similar to that in

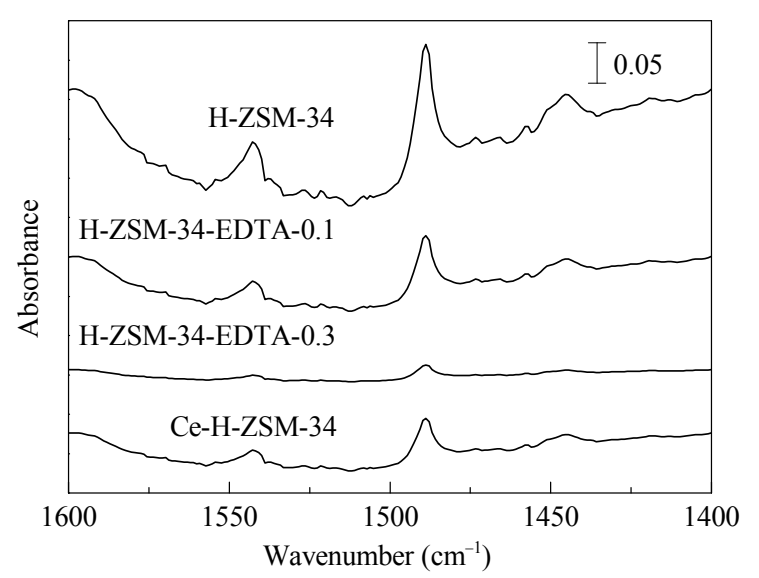

Fig. 6. FT-IR spectra of adsorbed pyridine for H-ZSM-34 samples treated with $\mathrm{Na}_{2} \mathrm{H}_{2}$ EDTA and modified with Ce together with parent H-ZSM-34.
H-ZSM-34 (Table 4), we speculate that the weaker Ce-H-ZSM-34 acidity results from the Ce ions existing in the cationic-exchanging position to replace some of the protons.

To gain further information about the acid sites, we performed FT-IR studies on adsorbed pyridine for H-ZSM-34, $\mathrm{Na}_{2} \mathrm{H}_{2}$ EDTA-treated H-ZSM-34, and Ce-modified H-ZSM-34 samples. As shown in Fig. 6, three IR bands at 1542, 1487, and $1450 \mathrm{~cm}^{-1}$ were observed for H-ZSM-34. The IR bands at 1542 and $1450 \mathrm{~cm}^{-1}$ could be attributed to the Brönsted and Lewis acid sites, respectively, while the band at $1487 \mathrm{~cm}^{-1}$ could originate from both the Brönsted and Lewis acid sites [32]. For the H-ZSM-34-EDTA and Ce-H-ZSM-34 samples, the intensities of the IR bands belonging to both the Brönsted and Lewis acid sites decrease compared with those for H-ZSM-34. This demonstrates that the $\mathrm{Na}_{2} \mathrm{H}_{2}$ EDTA treatment and Ce modification could decrease densities of both the Brönsted and Lewis acid sites.

${ }^{27} \mathrm{Al}$ MAS NMR is an effective technique for gaining information on the coordination state of $\mathrm{Al}$ species. Generally, $\mathrm{Al}$ species in four-, five- and six-coordination environments exhibit signals at $\delta=55-60, \sim 30$, and $\sim 0$, respectively [33]. To obtain insight into the coordination of $\mathrm{Al}$ in our catalysts, Fig. 7 gives ${ }^{27} \mathrm{Al}$ MAS NMR spectra of H-ZSM-34, H-ZSM-34-EDTA, and Ce-H-ZSM-34 catalysts. H-ZSM-34 without any treatment or modification showed a signal at $\delta=\sim 60$, which could be assigned to the tetrahedral $\mathrm{Al}$ in the framework of H-ZSM-34. No signals at $\delta=30$ and 0 were observed, indicating the absence of five- and six-coordinated Al species in H-ZSM-34. After treatment with $\mathrm{Na}_{2} \mathrm{H}_{2}$ EDTA, a weak signal at $\delta=0$ appeared, and this signal became stronger with increasing $\mathrm{Na}_{2} \mathrm{H}_{2}$ EDTA concentration. This indicates that octahedrally coordinated Al species, i.e., extra-framework Al species, formed during $\mathrm{Na}_{2} \mathrm{H}_{2}$ EDTA treatment. This is in agreement with our speculation that $\mathrm{Na}_{2} \mathrm{H}_{2}$ EDTA treatment leads to dealumination. For Ce-modified H-ZSM-34, a broad signal at $\delta=0$ was also observed, suggesting the appearance of an extra-framework $\mathrm{Al}$ in this sample. At the same time, the signal at $\delta=60$ became broader. These observations imply that several different types of $\mathrm{Al}$ species may exist in the Ce-H-ZSM-34.

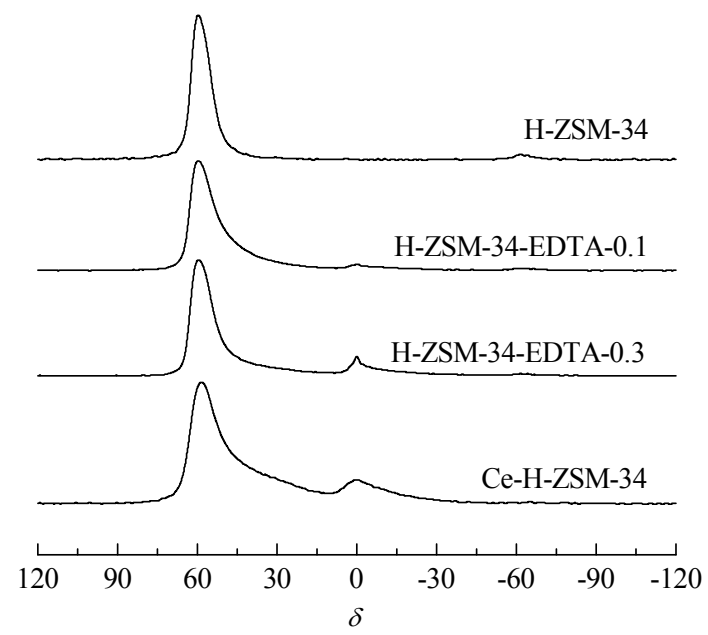

Fig. 7. ${ }^{27} \mathrm{Al}$ MAS NMR spectra of H-ZSM-34 samples treated with $\mathrm{Na}_{2} \mathrm{H}_{2}$ EDTA and modified with Ce together with parent H-ZSM-34. 


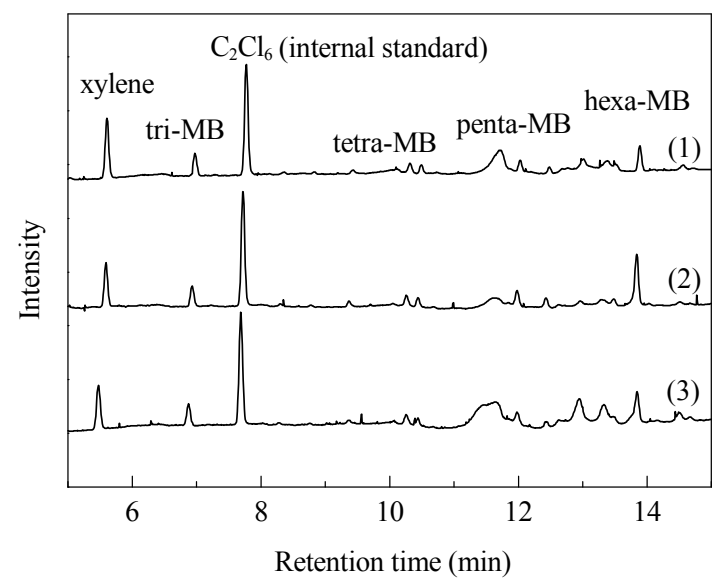

Fig. 8. GC-MS analyses of methylbenzene intermediates trapped in several catalysts after $2 \mathrm{~h}$ under conditions in Fig. 2. (1) H-ZSM-34; (2) H-ZSM-34-EDTA-0.1; (3) Ce-H-ZSM-34. $\mathrm{C}_{2} \mathrm{Cl}_{6}$ was used as internal standard for quantification of methylbenzenes. MB: methylbenzene.

\subsection{Possible reaction mechanism}

Many studies have contributed to understanding the reaction mechanism for the conversion of MTO. The "hydrocarbon pool" mechanism is a widely accepted mechanism $[3,18]$. It is proposed that methylbenzenes with different numbers of methyl substituents and the corresponding carbenium ions function as active intermediates or their stable forms or precursors in the "hydrocarbon pool" in the working catalyst for the production of lower olefins. A similar "hydrocarbon pool" mechanism has also been proposed for the conversion of methyl halides to lower olefins over H-SAPO-34 and H-ZSM-5 [21,26].

We analyzed the hydrocarbon compounds trapped in our used catalysts according to the method proposed by Bjørgen et al. [34]. After $2 \mathrm{~h}$, the catalyst was dissolved in HF solution and the organic compounds extracted by $\mathrm{CH}_{2} \mathrm{Cl}_{2}$ for $\mathrm{GC}-\mathrm{MS}$ analysis. As shown in Fig. 8, methylbenzenes with different methyl substituents were observed for H-ZSM-34, H-ZSM-34-EDTA, and Ce-H-ZSM-34 catalysts, suggesting that these methylbenzenes were the main organic compounds existing in the "hydrocarbon pools" over our catalysts. Figure 9 shows the distribution of methylbenzenes calculated from Fig. 8 for H-ZSM-34, H-ZSM34-EDTA-0.1, and Ce-H-ZSM-34 catalysts. Compared with H-ZSM-34, the fraction of tetra-, penta-, and hexa-methylbenzenes in the "hydrocarbon pool" increases over the H-ZSM-34EDTA-0.1, and Ce-H-ZSM-34 catalysts.

From the results obtained, we speculate that during the conversion of $\mathrm{CH}_{3} \mathrm{Cl}$, lower olefins may form from methylbenzene intermediates existing in the "hydrocarbon pool" as in the

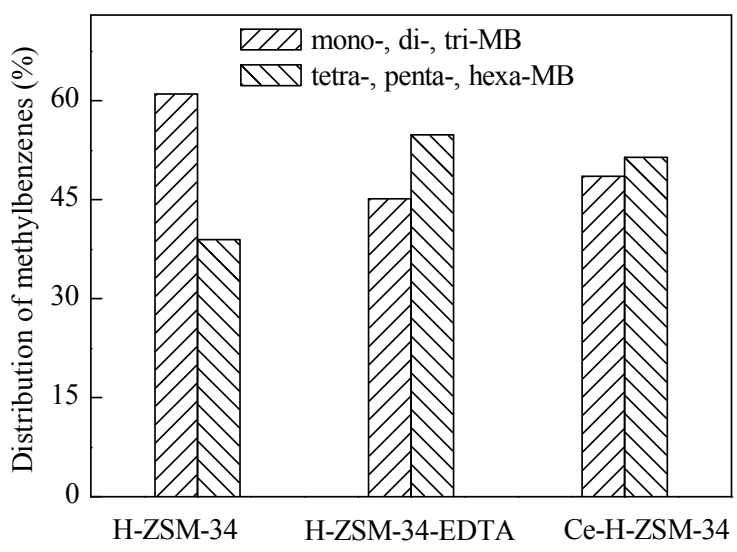

Fig. 9. Distribution of methylbenzene intermediates trapped in H-ZSM-34, H-ZSM-34-EDTA-0.1, and Ce-H-ZSM-34 catalysts after $2 \mathrm{~h}$ under conditions of Fig. 2.

MTO process. From our results with varying contact time, we suggest that the lower olefins, i.e., $\mathrm{C}_{2} \mathrm{H}_{4}, \mathrm{C}_{3} \mathrm{H}_{6}$, and $\mathrm{C}_{4} \mathrm{H}_{8}$, are formed as the primary products (Fig. 1). It is proposed that the conversion of $\mathrm{CH}_{3} \mathrm{Cl}$ over the H-ZSM-34-based catalysts proceeds according to the reaction mechanism in Scheme 1. We speculate that the formation of lower olefins from the methylbenzene intermediates may resemble that in the MTO process $[3,18]$. It has been reported that mono-, di-, and tri-methylbenzenes may be responsible for the formation of $\mathrm{C}_{2} \mathrm{H}_{4}$, whereas tetra-, penta-, and hexa-methylbenzenes may be responsible for the formation of $\mathrm{C}_{3} \mathrm{H}_{6}$ and $\mathrm{C}_{4} \mathrm{H}_{8}$ in the MTO process $[3,18]$. Thus, we tentatively suggest that the increase in fraction of tetra-, penta-, and hexa-methylbenzenes for catalysts with EDTA treatment or Ce modification may contribute to the increase in ratio of $\mathrm{C}_{3} \mathrm{H}_{6}$ to $\mathrm{C}_{2} \mathrm{H}_{4}$ in the final product. Further studies are required to understand the detailed reaction mechanism for the formation of $\mathrm{C}_{2} \mathrm{H}_{4}$ and $\mathrm{C}_{3} \mathrm{H}_{6}$ in the conversion of $\mathrm{CH}_{3} \mathrm{Cl}$.

It is proposed that the main byproducts, i.e., $\mathrm{C}_{2}-\mathrm{C}_{4}$ paraffins and $\mathrm{C}_{5+}$ hydrocarbons, form from the lower olefins via hydrogen transfer and/or aromatization reactions. For example, $\mathrm{C}_{2} \mathrm{H}_{6}, \mathrm{C}_{3} \mathrm{H}_{8}$, and $\mathrm{C}_{4} \mathrm{H}_{10}$ could be formed from $\mathrm{C}_{2} \mathrm{H}_{4}, \mathrm{C}_{3} \mathrm{H}_{6}$, and $\mathrm{C}_{4} \mathrm{H}_{8}$ via inter-molecular hydrogen transfer reactions. Generally, a high density of stronger acid sites is required for hydrogen transfer and aromatization reactions [35,36]. Our results indicate that $\mathrm{Na}_{2} \mathrm{H}_{2}$ EDTA treatment and Ce modification decrease the density of acid sites, particularly the density of the stronger Brönsted acidity of H-ZSM-34 (Figs. 5 and 6). This may suppress the further conversion of lower olefins over the H-ZSM-34-EDTA and Ce-H-ZSM-34 catalysts, thereby decreas-

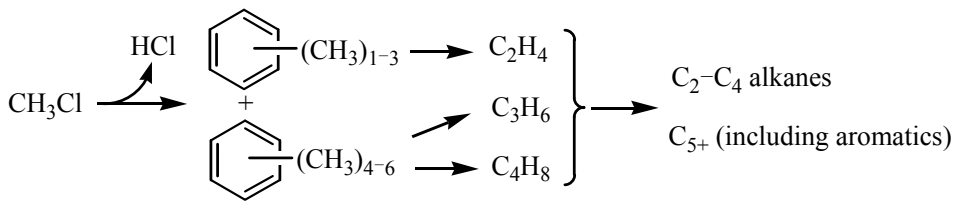

Intermediates in
"hydrocarbon pool"

Scheme 1. Proposed reaction mechanism for conversion of $\mathrm{CH}_{3} \mathrm{Cl}$ over $\mathrm{H}-\mathrm{ZSM}$-34-based catalysts. 
ing the selectivity to $\mathrm{C}_{2}-\mathrm{C}_{4}$ paraffins and $\mathrm{C}_{5+}$ hydrocarbons (Fig. 1). However, the conversion of $\mathrm{CH}_{3} \mathrm{Cl}$ decreases significantly over a catalyst with lower acidity such as H-ZSM-34-EDTA-0.3 (Table 2 and Fig. 5). This suggests that an appropriate acidity is required to obtain a higher selectivity to lower olefins and higher activity for $\mathrm{CH}_{3} \mathrm{Cl}$ conversion over the H-ZSM-34-based catalyst.

\section{Conclusions}

H-ZSM-34 exhibited a higher yield to lower olefins (i.e., $\mathrm{C}_{2} \mathrm{H}_{4}$, $\mathrm{C}_{3} \mathrm{H}_{6}$, and $\mathrm{C}_{4} \mathrm{H}_{8}$ ) in the conversion of $\mathrm{CH}_{3} \mathrm{Cl}$ than several other typical zeolites including H-ZSM-5, H-SAPO-34, H-SAPO-11, $\mathrm{H}-\beta, \mathrm{HY}, \mathrm{H}-\mathrm{MCM}-22$, and H-MOR. We demonstrated that the treatment of H-ZSM-34 with $\mathrm{Na}_{2} \mathrm{H}_{2}$ EDTA aqueous solution followed by ion exchange and calcination enhanced the selectivity and yield to lower olefins significantly. $\mathrm{Na}_{2} \mathrm{H}_{2}$ EDTA concentration is an important factor influencing catalytic behavior. At a $\mathrm{Na}_{2} \mathrm{H}_{2}$ EDTA concentration of $0.1 \mathrm{~mol} / \mathrm{L}$, the yield of lower olefins reached $61 \%$ with a $\mathrm{CH}_{3} \mathrm{Cl}$ conversion of $74 \%$ at $673 \mathrm{~K}$ and $\mathrm{CH}_{3} \mathrm{Cl}$ partial pressure of $9.2 \mathrm{kPa}$. Modification with rare earth metal ions is also an efficient means to promote the selectivity to lower olefins. Over the Ce-H-ZSM-34 catalyst, the selectivity to $\mathrm{C}_{3} \mathrm{H}_{6}$ is twice that without any modification, and a lower olefin yield of $60 \%$ was obtained. Characterization indicates that the acidity of H-ZSM-34, particularly the stronger Brönsted acidity, decreases by treatment with $\mathrm{Na}_{2} \mathrm{H}_{2}$ EDTA or modification with Ce ions. We propose that the decrease in stronger acidity may suppress the hydrogen transfer and aromatization reactions, which leads to the transformation of primary lower olefin products into $\mathrm{C}_{2}-\mathrm{C}_{4}$ paraffins and $\mathrm{C}_{5+}$ hydrocarbons and thus increases the selectivity to lower olefins.

\section{References}

[1] Cavani F, Ballarini N, Cericola A. Catal Today, 2007, 127: 113

[2] Liu G Y, Tian P, Liu Z M. Progr Chem (刘广宇, 田鹏, 刘中民. 化学 进展), 2010, 22: 1531

[3] Olsbye U, Svelle S, Bjøgen M, Beato P, Janssens T V W, Joensen F, Bordiga S, Lillerud K P. Angew Chem Int Ed, 2012, 51: 5810

[4] Holmen A. Catal Today, 2009, 142: 2

[5] Lunsford J H. Angew Chem Int Ed Eng, 1995, 34: 970
[6] Otsuka K, Wang Y. Appl Catal A, 2001, 222: 145

[7] Zhang Q H, Deng W P, Wang Y. Chem Commun, 2011, 47: 9275

[8] Schwarz H. Angew Chem Int Ed, 2011, 50: 10096

[9] Hammond C, Conrad S, Hermans I. ChemSusChem, 2012, 5: 1668

[10] He J L, Xu T, Wang Z H, Zhang Q H, Deng W P, Wang Y. Angew Chem Int $E d, 2012,51: 2438$

[11] Wang K X, Xu H F, Li W S, Zhou X P. J Mol Catal A, 2005, 225: 65

[12] Liu Z, Huang L, Li W S, Yang F, Au C T, Zhou X P. J Mol Catal A, 2007, 273: 14

[13] Lin R H, Ding Y J, Gong L F, Dong W D, Wang J H, Zhang T. J Catal, 2010, 272: 65

[14] Peringer E, Podkolzin S G, Jones M E, Olindo R, Lercher J A. Top Catal, 2006, 38: 211

[15] Podkolzin S G, Stangland E E, Jones M E, Peringer E, Lercher J A. J Am Chem Soc, 2007, 129: 2569

[16] Peringer E, Salzinger M, Hutt M, Lemonidou A A, Lercher J A. Top Catal, 2009, 52: 1220

[17] Stöcker M. Microporous Mesoporous Mater, 1999, 29: 3

[18] Haw J F, Song W, Marcus D W, Nicholas J B. Acc Chem Res, 2003, 36: 317

[19] Liu Z M, Liang J. Curr Opin Solid State Mater Sci, 1999, 4: 80

[20] Wei Y X, Zhang D Z, Liu Z M, Su B L. J Catal, 2006, 238: 46

[21] Wei Y X, Zhang D Z, Chang F X, Xia Q H, Su B L, Liu Z M. Chem Commun, 2009: 5999

[22] Svelle S, Aravinthan S, Bjørgen M, Lillerud K P, Kolboe S, Dahl I M, Olsbye U.J Catal, 2006, 241: 243

[23] Nilsen M H, Svelle S, Aravinthan S, Olsbye U. Appl Catal A, 2009, 367: 23

[24] Olsbye U, Saure O V, Muddada N B, Bordiga S, Lamberti C, Nilsen M H, Lillerud K P, Svelle S. Catal Today, 2011, 171: 211

[25] Zhang A H, Sun S L, Komon Z J A, Osterwalder N, Gadewar S, Stoimenov P, Auerbach D J, Stucky G D, McFarland E W. Phys Chem Chem Phys, 2011, 13: 2550

[26] Xu T, Zhang Q H, Song H, Wang Y. J Catal, 2012, 295: 232

[27] Vartuli J C, Kennedy G J, Yoon B A, Malek A. Microporous Mesoporous Mater, 2000, 38: 247

[28] Wu Z F, Song J W, Ji Y Y, Ren L M, Xiao F S. Chem Mater, 2008, 20: 357

[29] Anderson M W, Occelli M L, Klinowski J. J Phys Chem, 1992, 96: 388

[30] Zhou F, Tian P, Liu Z M, Liu G Y, Chang F X, Li J Z. Chin J Catal (周帆, 田鹏, 刘中民, 刘广宇, 常福祥, 李金哲. 催化学报), 2007, 28: 817

[31] Yang C G, Ren L M, Zhang H Y, Zhu L F, Wang L, Meng X J, Xiao F S. J Mater Chem, 2012, 22: 12238

[32] Koo J B, Jiang N, Saravanamurugan S, Bejblová M, Musilová Z,

\section{Graphical Abstract}

Chin. J. Catal., 2013, 34: 2047-2056 doi: 10.1016/S1872-2067(12)60681-0

\section{Catalytic conversion of methyl chloride to lower olefins over modified H-ZSM-34}

Ting Xu, Hang Song, Weiping Deng*, Qinghong Zhang, Ye Wang* Xiamen University

H-ZSM-34 was an efficient catalyst for the conversion of methyl chloride to lower olefins. The treatment of H-ZSM-34 with $\mathrm{Na}_{2} \mathrm{H}_{2}$ EDTA or modification with Ce further enhanced the lower olefin yield to $60 \%-61 \%$.

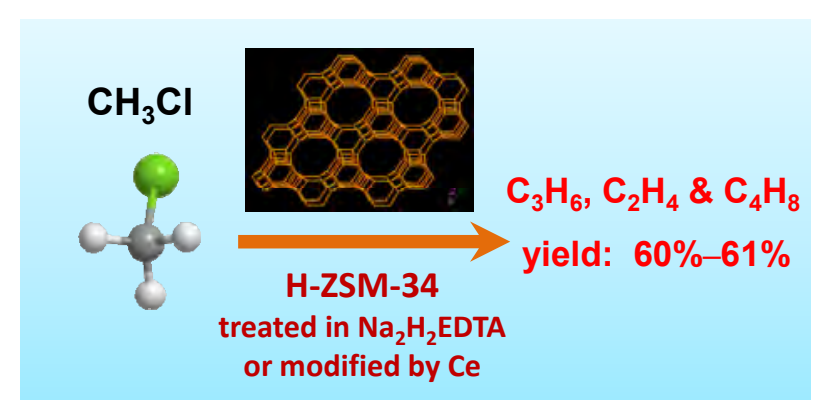


Čejka J, Park S E. J Catal, 2010, 276: 327

[33] Klinowski J. Chem Rev, 1991, 91: 1459

[34] Bjørgen M, Svelle S, Joensen F, Nerlov J, Kolboe S, Bonino F, Palumbo L, Bordiga S, Olsbye U.J Catal, 2007, 249: 195
[35] Corma A, González-Alfaro V, Orchillés A V. Appl Catal A, 1999, 187: 245

[36] Zhang D Z, Wei Y X, Xu L, Chang F X, Liu Z Y, Meng S H, Su B L, Liu Z M. Microporous Mesoporous Mater, 2008, 116: 684

\title{
改性H-ZSM-34上氯甲烷催化转化制低碳烯烃
}

\author{
徐霆，宋 航，邓卫平”，张庆红，王 野* \\ 厦门大学化学化工学院, 能源材料化学协同创新中心, 固体表面物理化学国家重点实验室, \\ 醇醚酯化工清洁生产国家工程实验室，福建厦门361005
}

摘要: 比较了几种典型的沸石分子篎在氯甲烷转化制乙烯、丙烯和丁烯等低碳烯烃反应中的催化性能, 发现H-ZSM-34具有较佳 的催化活性和选择性. 经乙二胺四乙酸二钠 $\left(\mathrm{Na}_{2} \mathrm{H}_{2} \mathrm{EDTA}\right)$ 水溶液处理, 并经离子交换及焙烧后, H-ZSM-34上氯甲烷转化制低碳烯 烃的催化性能显著改善. 当 $\mathrm{Na}_{2} \mathrm{H}_{2} \mathrm{EDTA}$ 浓度为 $0.1 \mathrm{~mol} / \mathrm{L}$, 反应温度为 $673 \mathrm{~K}, \mathrm{CH}_{3} \mathrm{Cl}$ 分压 $9.2 \mathrm{kPa}$ 时, $\mathrm{C}_{2}-\mathrm{C}_{4}$ 烯烃选择性和收率分别达 $82 \%$ 和 $61 \%$. 研究还发现, Ce修饰H-ZSM-34催化剂同样可改善氯甲烷制低碳烯烃的选择性和收率. 表征结果表明, $\mathrm{Na}_{2} \mathrm{H}_{2}$ EDTA处 理和Ce修饰均降低了H-ZSM-34的酸性. 酸性的降低可抑制低碳烯烃的氢转移反应, 继而避免了其进一步转化为低碳烷烃.

关键词：氯甲烷；低碳烯烃；H-ZSM-34；乙二胺四乙酸二钠处理；铈修饰；酸性

收稿日期: 2013-07-04. 接受日期: 2013-08-16. 出版日期: 2013-11-20.

*通讯联系人.电话：(0592)2186156; 传真：(0592)2183047; 电子信箱：wangye@xmu.edu.cn

通讯联系人.电话：(0592)2180480; 传真：(0592)2183047; 电子信箱：dengwp@xmu.edu.cn

基金来源：国家重点基础研究发展计划(973计划, 2010CB732303); 国家自然科学基金(21173174，20923004，21033006, 21161130522); 教育部长江学者与创新团队发展计划(IRT1036).

本文的英文电子版由Elsevier出版社在ScienceDirect上出版(http://www.sciencedirect.com/science/journal/18722067). 